Total polyphenol content and antioxidant activity of wild and cultivated asparagus in Croatia

Sadržaj ukupnih polifenola i antioksidacijska aktivnost samonikle i kultivirane šparoge u Hrvatskoj

Palfi, M., Jurković, Z., Ćosić, J., Tomić-Obrdalj, H., Jurković, V., Knežević, N., Vrandečić, K.

Poljoprivreda/Agriculture

ISSN: $1848-8080$ (Online)

ISSN: 1330-7142 (Print)

http://dx.doi.org/10.18047/poljo.23.1.9

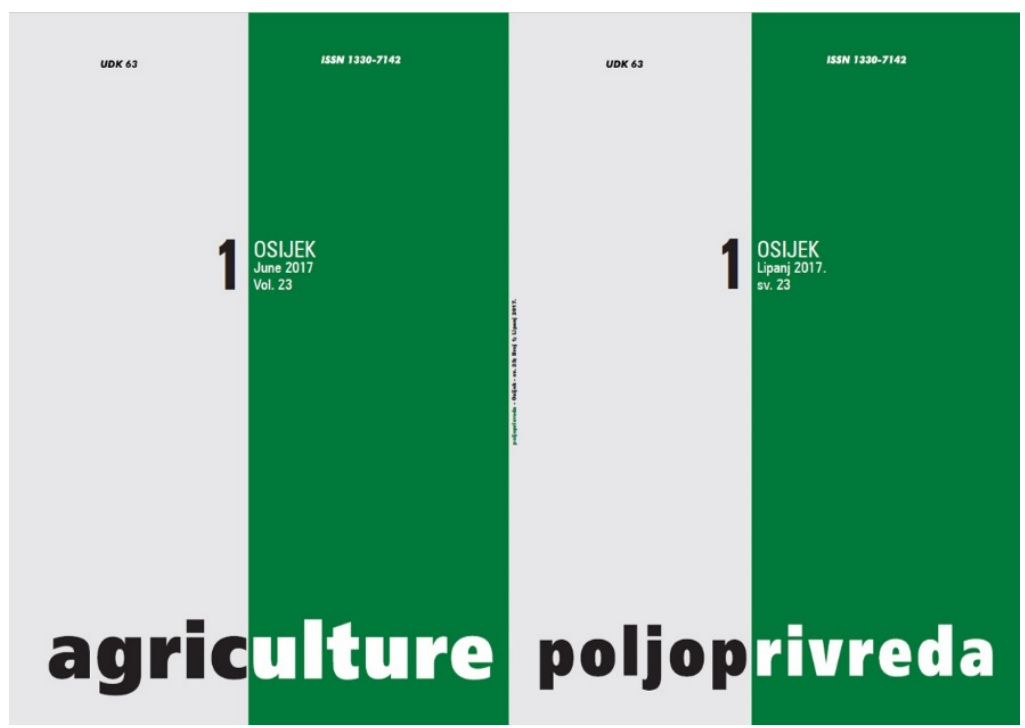

Poljoprivredni fakultet u Osijeku, Poljoprivredni institut Osijek

Faculty of Agriculture in Osijek, Agricultural Institute Osijek 


\section{TOTAL POLYPHENOL CONTENT AND ANTIOXIDANT ACTIVITY OF WILD AND CULTIVATED ASPARAGUS IN CROATIA}

Palfi, M.(1), Jurković, Z.(2), Ćosić, J.(3), Tomić-Obrdalj, H.(1), Jurković, V.(2), Knežević, N.(1), Vrandečić, K.(3)

Original scientific paper

Izvorni znanstveni članak

\section{SUMMARY}

Asparagus is an interesting vegetable as a part of a healthy diet and has been widely studied due to the high nutritional value and potential positive effects on human health. Wild asparagus (Asparagus acutifolius L.) grows along the Adriatic coast and islands, while the cultivated asparagus (A. officinalis L.) is mostly grown in the eastern region of Croatia. The aim of this study was to determine total polyphenol content (measured spectrophotometrically) and antioxidant activity (DPPH) in wild and cultivated asparagus. No significant differences in total polyphenol content were found between wild and cultivated asparagus. The highest content of polyphenols in wild asparagus was 6.20 [mg GAE/g fresh weight] and 49.60 [mg GAE/g dry weight], and in cultivated asparagus it was 4.52 [mg GAE/g fresh weight] and 50.93 [mg GAE/g dry weight].

Antioxidant activity measured using DPPH (2,2-diphenyl-1-picrylhydrazyl) method showed statistically significant difference. Higher antioxidant activity was measured in cultivated than in wild asparagus. The results also indicate that increased polyphenol content leads to higher antioxidant activity, but more so in the cultivated asparagus. Based on the results, the cultivated asparagus is an excellent alternative to wild asparagus that should be protected from over-harvesting, thus preventing devastation of plant diversity of islands and coast.

Key-words: Asparagus acutifolius L., Asparagus officinalis L., DPPH, total polyphenol, antioxidant activity.

\section{INTRODUCTION}

Diet rich in fruits and vegetables has a protective effect on human health that is primarily attributed to their polyphenolic content (Liu et al., 2014). Phenolic compounds constitute a major part of antioxidants in plants (Duthie and Crozier, 2000) and their contribution to the antioxidant activity is greater than that of vitamin C (Liu et al., 2014). Most of the natural antioxidants proved to be safer for health with better antioxidant activity, unlike the synthetic antioxidants that have been questioned due to their health risks (Krishnaiah et al., 2007).

Asparagus is vegetable that contains flavonoids (mainly rutin) and other phenolic compounds, which possess strong antioxidant properties (Makris and Rossiter, 2001; Guillén et al., 2008; Lee et al., 2014; Solana et al., 2015). The potential health benefits of antioxidants in asparagus include reducing the risk of cancer, cardiovascular diseases, cerebrovascular diseases, and other diseases (García Giménez et al., 2012; Wang et al., 2013; Palfi et al., 2014) and are therefore subject of a number of studies on their effects on health (Hafizur et al., 2012; Nishimura et al., 2013; Zhong et al., 2015). Due to the rich source of antioxidants, asparagus and asparagus by-products can be used as bioactive components in foods and are potential functional food ingredient in the food industry (Di Maro et al., 2013; Agudelo Cadavid et al., 2015).

(1) Marina Palfi, MSc (marina.palfi@podravka.hr), Nada Knežević, PhD, Helena Tomić Obrdalj, Univ. Spec. - Podravka d.d., Ante Starčevića 32, 48000 Koprivnica, Croatia, (2) Vlatka Jurković, BSc, Zorica Jurković, PhD - Agricultural Institute Osijek, Južno predgrađe 17, 31000 Osijek, Croatia, (3) Prof. Dr. Jasenka Ćosić, Assoc. Prof. Karolina Vrandečić - Josip Juraj Strossmayer University of Osijek, Faculty of Agriculture in Osijek, Vladimira Preloga 1, 31000 Osijek, Croatia 
Wild asparagus plays an important role in the culinary tradition of the Adriatic coast and islands' population (Žaper, 2004). Growing cultivated asparagus in Croatia is in its initial stages and is significantly present only in the eastern parts of the country.

The aim of this study was to determine differences in the total phenol content and antioxidant capacity of wild asparagus (A. acutifolius $\mathrm{L}$.) of the island of Pag and cultivated asparagus (A. officinalis L.) grown in Croatia near Vinkovci.

\section{MATERIAL AND METHOD}

\section{Plant material}

Samples of wild asparagus (A. acutifolius L.) were collected in early April 2014 at four locations on the island of Pag and the surrounding area, while samples of cultivated green asparagus ( $A$. officinalis L.) were collected at the same time at four locations around Vinkovci, Croatia (Table 1). Identification of plant material was made at the Faculty of Agriculture in Osijek.

Table 1. Location of the tested asparagus

Tablica 1. Lokacija ispitivanih šparoga

\begin{tabular}{|c|c|c|c|}
\hline $\begin{array}{l}\text { Plant species } \\
\text { Biljna vrsta }\end{array}$ & $\begin{array}{l}\text { Location } \\
\text { Lokacija }\end{array}$ & \multicolumn{2}{|c|}{$\begin{array}{l}\text { Location coordinates } \\
\text { Koordinate lokacija (Google Earth) }\end{array}$} \\
\hline Asparagus acutifolius $\mathrm{L}$. & Ražanac & $44^{\circ} 16^{\prime} 56.08^{\prime \prime S}$ & $15^{0} 20^{\prime} 52.71^{\prime \prime} \mid$ \\
\hline Asparagus acutifolius $\mathrm{L}$. & Šimuni & $44^{\circ} 28^{\prime} 04.63^{\prime \prime S}$ & $14^{\circ} 57^{\prime} 38.94^{\prime \prime} \mid$ \\
\hline Asparagus acutifolius $\mathrm{L}$. & Dabovi Stani & $44^{\circ} 36^{\prime} 06.97^{\prime \prime S}$ & $14^{\circ} 50^{\prime} 26.45^{\prime \prime} \mid$ \\
\hline Asparagus acutifolius $\mathrm{L}$. & Lun & $44^{\circ} 41^{\prime} 10.87^{\prime \prime S}$ & $14^{\circ} 45^{\prime} 01.89^{\prime \prime} \mid$ \\
\hline Asparagus officinalis $\mathrm{L}$. & Rokovci 1 & $45^{\circ} 14^{\prime} 33.06^{\prime \prime} \mathrm{S}$ & $18^{\circ} 45^{\prime} 35.51^{\prime \prime} \mid$ \\
\hline Asparagus officinalis L. & Rokovci 2 & $45^{0} 13^{\prime} 50.08^{\prime \prime S}$ & $18^{\circ} 44^{\prime} 32.77^{\prime \prime} \mid$ \\
\hline Asparagus officinalis L. & Andrijaševci & $45^{\circ} 13^{\prime} 33.99^{\prime \prime S}$ & $18^{\circ} 44^{\prime} 19.34^{\prime \prime} \mid$ \\
\hline Asparagus officinalis L. & Ivankovo & $45^{\circ} 17^{\prime} 18.64^{\prime \prime} \mathrm{S}$ & $18^{\circ} 44^{\prime} 08.80^{\prime \prime} \mid$ \\
\hline
\end{tabular}

Each sample of asparagus (wild and cultivated) contained 20 shoots of $17-20 \mathrm{~cm}$ length. After harvest, spears were wrapped in plastic and placed immediately on ice for transport to Agrochemical laboratory of the Agricultural Institute Osijek where the analyses were performed.

\section{Reagents and Chemicals}

Chemicals including high performance liquid chromatography (HPLC)-grade methanol, were purchased from J.T.Baker Inc. (New Jersey, USA); 2.2-diphenylpicrylhydrazyl, $\leq 100 \%$ and Gallic acid were purchased from Sigma-Aldrich Chemical Company (St Louis, MO, USA), Folin-Ciocalteu $2 \mathrm{M}$ phenol reagent was purchased from Kemika (Zagreb, Croatia). All chemicals used in this study were of analytical grade (Gallic acid, Folin-Ciocalteu $2 \mathrm{M}$ phenol reagent, sodium carbonate).

\section{Extraction procedure}

$24 \mathrm{~h}$ after harvesting, spears of fresh green asparagus were flash-frozen in liquid nitrogen and stored at $-20^{\circ} \mathrm{C}$. Frozen samples were homogenized in blender, weighed $(\sim 2 \mathrm{~g})$, and total polyphenols were extracted with $5 \mathrm{~mL}$ of acidified methanol (1\% hydrochloric acid) for $60 \mathrm{~min}$ in an ultrasonic bath (Sonorex RH $510 \mathrm{H}$, Bandelin electronics, Berlin, Germany) and reextracted with $5 \mathrm{~mL}$ of acidified methanol (1\% hydrochloric acid) for $30 \mathrm{~min}$. After centrifugation (LC-320, Tehtnica, Slovenija) at $4^{\circ} \mathrm{C}$ and $9000 \mathrm{rpm}$ for $10 \mathrm{~min}$, supernatant was used for spectrophotometrical determination of total polyphenols (Escarpa and Gonzales, 2000).

\section{Total polyphenol content}

Total polyphenols were determined by FolinCiocalteu method (Slinkard and Singleton, 1977) modi- fied in micro method as follows. An aliquot (100 $\mu \mathrm{L})$ was mixed with $2000 \mu \mathrm{L}$ of sodium carbonate solution $(2 \% \mathrm{w} / \mathrm{v})$ and $100 \mu \mathrm{L}$ of Folin-Ciocalteu reagent. After incubation at room temperature for $30 \mathrm{~min}$ in dark, the absorbance was read against the blank at $765 \mathrm{~nm}$ (Specord 200, Analytic Jena, Germany). Total polyphenols were expressed as $\mathrm{mg}$ of gallic acid equivalents (GAE) $\mathrm{g}^{-1}$ for fresh weight (FW), and dry weight (DW) of the plant respectively (Waterhouse, 2002). The measurement was carried out in three replicates and data are showed as a mean value.

\section{The DPPH radical scavenging activity - The percenta- ge of antioxidant activity (aa\%)}

DPPH (2.2-diphenyl-1-picryl-hydrazyl-hydrate) free radical method is an antioxidant assay based on electron-transfer that produces a violet solution in ethanol. This free radical, stable at room temperature, is reduced in the presence of an antioxidant molecule, giving rise to colourless ethanol solution. The use of the DPPH assay provides an easy and rapid way to evaluate antioxidants by spectrophotometry, so it can be useful to assess various products at a time.

The percentage of antioxidant activity (aa\%) was assessed by DPPH free radical assay. The measurement of the DPPH radical scavenging activity was performed according to methodology described by Brand-Williams et al. (1995). The samples were reacted with the stable DPPH radical in methanol solution. The reaction mixture consisted of adding $0.2 \mathrm{~mL}$ of sample, $2 \mathrm{~mL}$ of methanol and $1 \mathrm{~mL}$ of DPPH radical solution $0.5 \mathrm{mM}$ in methanol. When DPPH reacts with an antioxidant compound, which can donate hydrogen, it is reduced. The changes 
in colour were read [absorbance (abs)] at $517 \mathrm{~nm}$ after 100 min of reaction using a UV-ViS spectrophotometer (Specord 200, Analytic Jena, Germany). The mixture of methanol $(3.3 \mathrm{~mL})$ and sample $(0.5 \mathrm{~mL})$ serve as blank. The control solution was prepared by mixing methanol $(3.5 \mathrm{~mL})$ and DPPH radical solution $(0.3 \mathrm{~mL})$. The scavenging activity percentage $(\mathrm{a} \%)$ was determined according to Mensor et al. (2001). The measurement of antioxidant activity was carried out in three replicates and data were presented in two ways. The first one is aa\%, which is calculated according to free radical inhibition, the concentration of extract needed for inhibition of $50 \%$ DPPH radicals. The second one is calculated according to standard curve with gallic acid as standard. Antioxidant activity is given expressed as the equivalent of gallic acid needed for reducing initial concentration of free radicals.

\section{Statistical analysis}

Comparison of total polyphenols, as well as the comparison of antioxidant activity between wild and cultivated samples was carried out by using a multivariate permutation test, a modern version of the Hoteling $\mathrm{t}$-test. The correlation between the content of total poly-

A

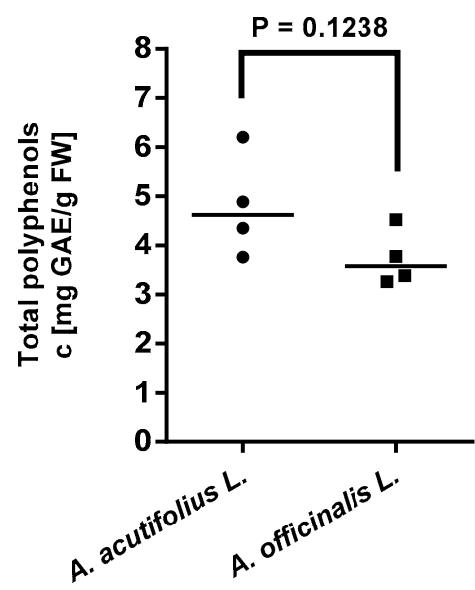

phenols and antioxidant effect was carried out by using a non-parametric correlation (Pearson's linear regression (r) and $p$ value for correlation) (Bonnini et al., 2014). Statistical analyses were carried out in the programs PAST (v. 2.17) (Hammer et al., 2001) and GraphPad Prism for Windows (v. 5) (GraphPad Software, 2013). Results were considered statistically significant at $\mathrm{p}$ $<0.05$. All applied tests were two-tailed.

\section{RESULTS AND DISCUSSION}

Asparagus is recognized as a good source of polyphenolic compounds with significant antioxidant capacity. According to recent findings, the wild asparagus from the island of Pag, Croatia, and the surrounding area, haven't been analysed and compared yet with the cultivated asparagus. The analysis of total polyphenol content and antioxidant capacity was done and their mutual correlation was examined.

\section{Total polyphenol content}

The highest content of polyphenols in wild asparagus was 6.20 [mg GAE/g FW] and 49.60 [mg GAE/g $\mathrm{DW}$, and in cultivated asparagus, it was 4.52 [mg $\mathrm{GAE} / \mathrm{g} \mathrm{FW}$ ] and 50.93 [mg GAE/g DW] (Fig. 1).
B

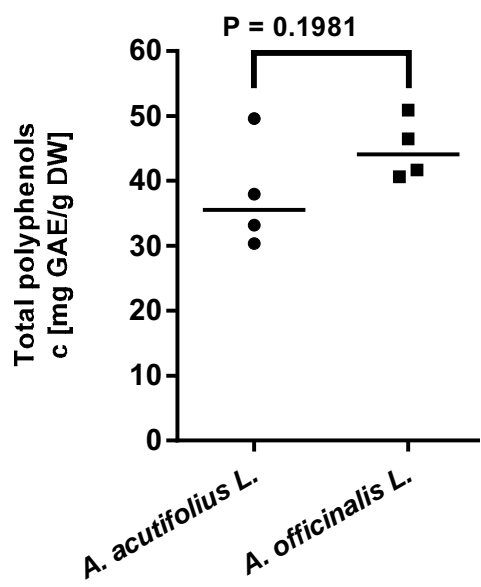

Figure 1. Total polyphenol content in wild (A. acutifolius L.) and cultivated (A. officinalis L.) asparagus: A-fresh weight, B-dry weight

Grafikon 1. Sadržaj ukupnih polifenola u samonikloj (A. acutifolius L.) i kultiviranoj (A. officinalis L.) šparogi: A-svježa tvar, $B$-suha tvar

The difference in total phenol content between wild and cultivated asparagus was not statistically significant. Sun et al. (2007) found that the total phenol content of asparagus ( $A$. officinalis) in acetone, methanol and aqueous extract, was $5.0 \pm 0.5,4.9 \pm 0.7$, and $4.9 \pm 0.9$ [mg catehin equivalent $/ \mathrm{g}$ dry weight], respectively. The investigation of Istrian wild asparagus showed that the results for the $40 \% \mathrm{EtOH}$ and $96 \% \mathrm{EtOH}$ extract of wild asparagus were $793 \pm 33 \mathrm{mg} \mathrm{GAE} / 100 \mathrm{~g}$ DW and $181 \pm 26 \mathrm{mg} \mathrm{GAE} / 100 \mathrm{~g} \mathrm{DW}$, respectively (Poljuha et al., 2015). Very high content of phenolic compounds was found in the Portuguese wild asparagus:
$624 \pm 28 \mathrm{mg} \mathrm{GAE} / \mathrm{g}$ of extract (Martins et al., 2011), but in the Spanish one, it was only $17.60 \pm 0.29 \mathrm{mg} \mathrm{GAE} / \mathrm{g}$ of extract (Morales et al., 2012).

The results of our analysis are not in accordance with the Ferrara et al. (2011), the study which found that the phenolic content of $A$. acutifolius $(41.97 \pm 1.95$ $\mathrm{mg} / 100 \mathrm{~g})$ was higher compared to $A$. officinalis $(27.62 \pm 1.11 \mathrm{mg} / 100 \mathrm{~g})$. From the foregoing, it can be concluded that the phenolic profile of populations from different geographical areas varies considerably (Poljuha et al., 2015). However, large differences can 
be partly explained by various analysis modifications both in the extraction of polyphenols and in the results. Phenol biosynthesis in plants is dependent on a number of environmental factors, such as UV radiation, soil, biotic or abiotic stress (Cheynier et al., 2013); it is also dependent on the timing of the harvest of asparagus (Lee et al., 2014). Cultivation conditions, especially light conditions, are of great importance for the rutin and polyphenol content (Maeda et al., 2010).

A

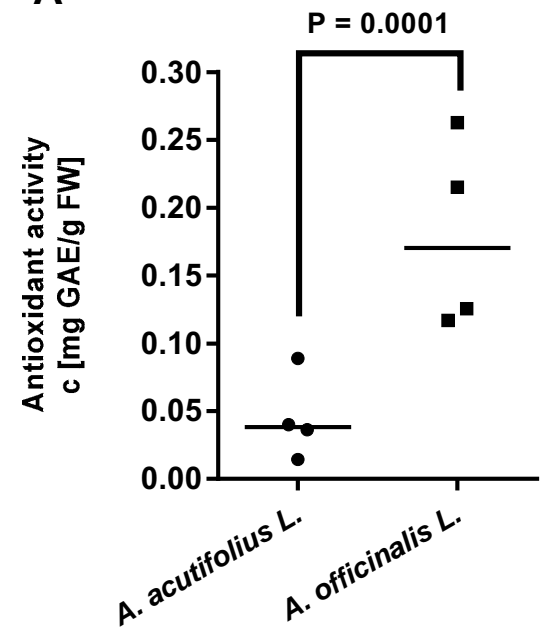

\section{Antioxidant activity}

The highest antioxidant activity for cultivated asparagus were 0.26 [mg GAE/g FW] and 2.83 [mg GAE/g $\mathrm{DW}$ ], and the lowest 0.12 [mg GAE/g FW] and 1.61 [mg $\mathrm{GAE} / \mathrm{g} \mathrm{DW}]$. The highest antioxidant activity for wild asparagus were $0.09[\mathrm{mg} \mathrm{GAE} / \mathrm{g} \mathrm{FW}]$ and $0.7[\mathrm{mg} \mathrm{GAE} / \mathrm{g}$ DW], and lowest 0.01 [mg GAE/g FW] and $0.1[\mathrm{mg} \mathrm{GAE} / \mathrm{g}$ DW]. In contrast to the content of total polyphenols, antioxidant activity showed statistically significant difference when comparing wild to cultivated asparagus (Fig. 2).

\section{B}

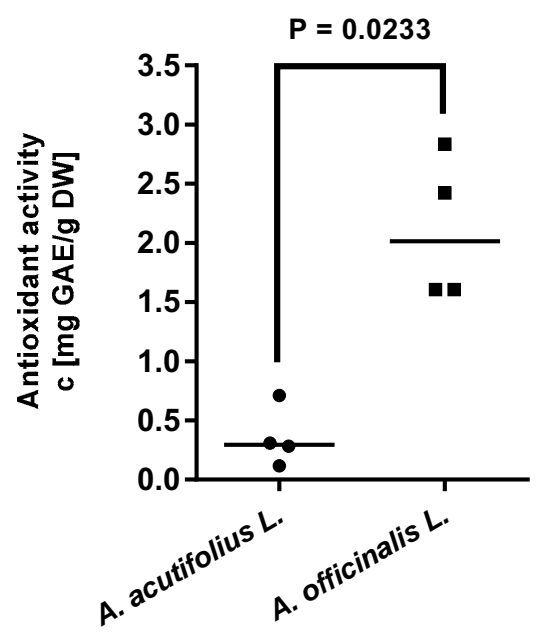

Figure 2. Antioxidant activity in wild (A. acutifolius L.) and cultivated (A. officinalis L.) asparagus: A-fresh weight, B-dry weight

Grafikon 2. Antioksidativna aktivnost samonikle (A. acutifolius L.) i kultivirane (A. officinalis L.) šparoge: A-svježa tvar, B-suha tvar

Antioxidant capacity of Istrian wild asparagus measured by DPPH method (mmoL TE/100 $\mathrm{g} \mathrm{DW}$ ) was $1.1 \pm 0.3$ in aqueous solution, $0.9 \pm 0.3$ in $40 \% \mathrm{EtOH}$ and $0.3 \pm 0.1$ in $96 \%$ EtOH (Poljuha et al., 2015). Using the same method Tiveron et al. (2012) found the value of $15.8 \pm 0.38 \mu \mathrm{moL}$ Trolox $/ \mathrm{g}$ DW for Brazilian asparagus
(A. officinalis), and the results of Solana et al. (2015) were in the range of 1.18 to 2.49 (rutin equivalent $\mathrm{mg} / \mathrm{g}$ ).

The statistics have showed the significant difference between wild and cultivated asparagus, calculating the 50\% DPPH (Fig. 3).

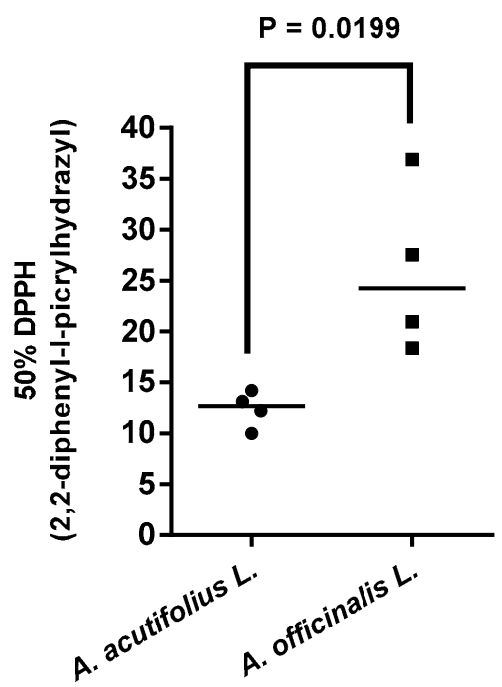

Figure 3. Inhibition $\mathbf{5 0}$ \% DPPH in wild (A. acutifolius $\mathrm{L}$.) and cultivated (A. officinalis $\mathrm{L}$.) asparagus Grafikon 3. Inhibicija 50\% DPPH samonikle (A. acutifolius L.) i kultivirane (A. officinalis L.) šparoge 
The lowest measured value of $50 \% \mathrm{DPPH}$ of wild asparagus was 9.99 , and the highest 14.20 , while for the cultivated one, the lowest amount was 18.38, and the highest 36.91. Ferrara et al. (2011) compared $A$. acutifolius and $A$. officinalis for $\mathrm{IC}_{50} \mathrm{DPPH}$ and measured 72.4 and $89.0 \mu \mathrm{g} / \mathrm{mL}$, respectively. Measuring antioxidant activity by DPPH of Spanish wild asparagus, $\mathrm{EC}_{50}$ $\mathrm{mg} / \mathrm{mL}$ was $4.87 \pm 0.38$ (Morales et al., 2012), and for

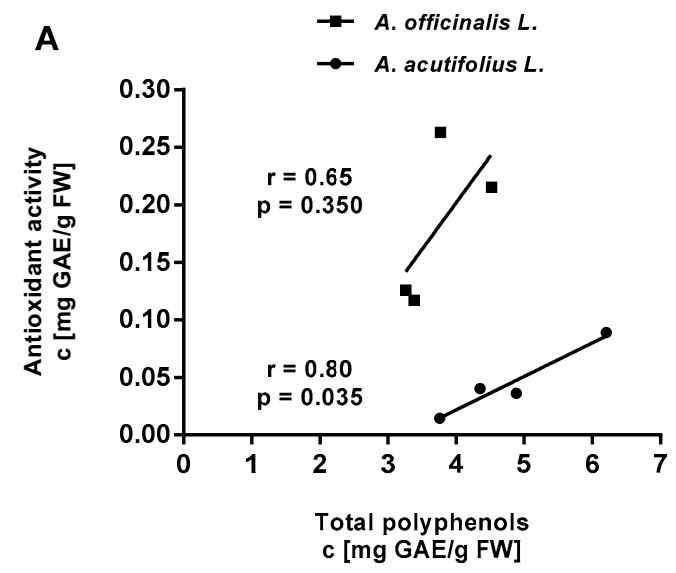

the Portuguese wild asparagus, the value $\mathrm{EC}_{50} \mu \mathrm{g} / \mathrm{mL}$ was $423 \pm 24$ (Martins et al., 2011).

Non-parametric correlation analysis of our results showed the relations between the total polyphenols and antioxidant activity; it has been proven that the increase of the content of polyphenol increases the antioxidant activity, in both fresh and dry matter, but more in cultivated asparagus (Fig. 4).

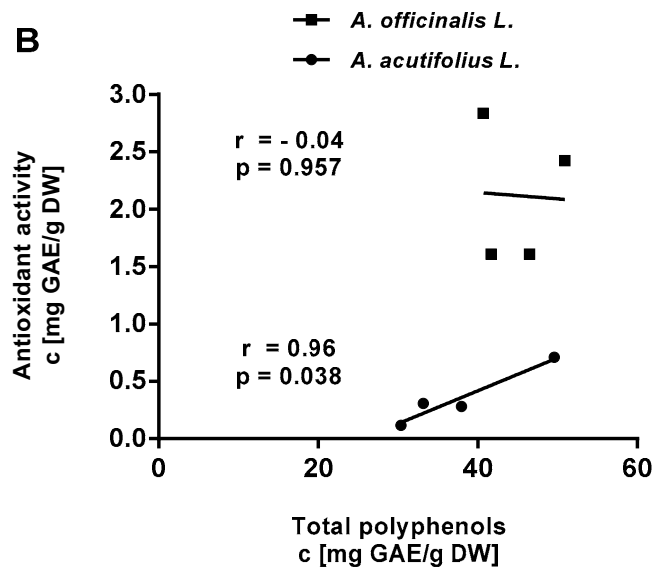

Figure 4. Correlation of antioxidant activity and total polyphenols in wild (A. acutifolius $L$.) and cultivated (A. officinalis L.) asparagus: A-fresh weight, B-dry weight Grafikon 4. Korelacija antioksidativne aktivnosti i ukupnih polifenola u samonikloj (A. acutifolius L.) i kultiviranoj (A. officinalis L.) šparogi: A-svježa tvar, B-suha tvar

Our results are consistent with the results of studies which have found a positive correlation between antioxidant activity and polyphenol content (Sun et al., 2007; Conforti et al., 2011; Cheng et al., 2013; Poljuha et al., 2015), while Tiveron et al. (2012) found the highest correlations for DPPH and FRAP methods, but did not find correlation for Rancimat method. Different values for antioxidant activity between wild and cultivated asparagus can be attributed, not only to polyphenol content, but other factors such as content of flavonoids, vitamin $\mathrm{C}$ and sulphate, production year, and especially the temperature range (Takács-Hájos and Zsombik, 2015) and the time of harvest (Lee et al., 2014).

\section{CONCLUSION}

The results of this study showed no statistically significant differences in the content of total polyphenols between wild and cultivated asparagus; however, antioxidant activity of cultivated asparagus is higher than the one of the wild species. Favourable agro-climatic growing conditions in Eastern Slavonia, adequate nutrition and good care of the crops possibly contribute to higher antioxidant activity of cultivated asparagus. Based on the results, we can conclude that the cultivated asparagus is an excellent alternative to wild asparagus that should be protected from over-harvesting, thus preventing the devastation of plant diversity of Croatian islands and coast.

\section{REFERENCES}

1. Agudelo Cadavid, E.L., Restrepo Molina, D.A., Cartagena Valenzuela, J.R. (2015): Chemical, physicochemical and functional characteristics of dietary fiber obtained from asparagus byproducts (Asparagus officinalis L.). Revista Facultad Nacional de Agronomía, Medellín, 68: 75337544.

doi: http://dx.doi.org/10.15446/rfnam.v68n1.47842

2. Bonnini, S., Corain, L., Marozzi, M., Salmaso, L. (2014): Nonparametric hypothesis testing: rank and permutation methods with applications in R. Chichester, John Wiley \& Sons, 1-37.

3. Brand-Williams, W., Cuvelier, M.E., Berset, C. (1995): Use of free radical method to evaluate antioxidant activity. LWT-Food Science and Technology, 28: 25-30. doi: http://dx.doi.org/10.1016/S0023-6438(95)80008-5

4. Cheynier, V., Comte, G., Davie, K.M., Lattanzio, V., Martens, S. (2013): Plant phenolics: recent advances on their biosynthesis, genetics, and ecophysiology. Plant Physiology and Biochemistry, 72: 1-20.

doi: http://dx.doi.org/10.1016/j.plaphy.2013.05.009

5. Conforti, F., Marrelli, M., Carmela, C., Menichini, F., Valentina, P., Uzunov, D., Menichini, F. (2011): Bioactive phytonutrients (omega fatty acids, tocopherols, polyphenols), in vitro inhibition of nitric oxide production and free radical scavenging activity of non-cultivated 
Mediterranean vegetables. Food Chemistry, 129: 14131419.

doi: http://dx.doi.org/10.1016/j.foodchem.2011.05.085

6. Di Maro, A., Pacifico, S., Fiorentino, A., Galasso, S., Gallicchio, M., Guida, V., Severino, V., Monaco, P., Parente, A. (2013): Raviscanina wild asparagus (Asparagus acutifolius L.): A nutritionally valuable crop with antioxidant and antiproliferative properties. Food Research International, 53: 180-188.

doi: http://dx.doi.org/10.1016/j.foodres.2013.04.026

7. Duthie, G., Crozier, A. (2000): Plant-derived phenolic antioxidants. Current Opinion in Lipidology, 11: 43-47.

8. Escarpa, A., Gonzales, M.C. (2000): Optimization strategy and validation of one chromatographic method as approach to determine the phenolic compounds from different sources. Journal of Chromatography A, 897: 161-170.

doi: http://dx.doi.org/10.1016/S0021-9673(00)00817-7

9. Ferrara, L., Dosi, R., Di Maro, A., Guida, V., Cefarelli, G., Pacifico, S., Parente, A. (2011): Nutritional values, metabolic profile and radical scavenging capacities of wild asparagus (A. acutifolius L.). Journal of Food Composition and Analysis, 24: 326-333.

doi: http://dx.doi.org/10.1016/j.jfca.2010.10.008

10. García Giménez, M.D., De la Puerta, R., Sáenz, M.T., Marquez-Martín, A., Fernández-Arche, M.A. (2012): Hypocholesterolemic and hepatoprotective effects of "Triguero" asparagus from Andalusian in rats fed a high cholesterol diet. Evidence-Based Complementary and Alternative Medicine (https://www.hindawi.com/journals/ecam/2012/814752).

doi: http://dx.doi.org/10.1155/2012/814752

11. Graph-Pad Software, San Diego, CA, USA. Available online: http://www.graphpad.com (accessed on 26 November 2013).

12. Guillén, R., Rodríguez, R., Jaramillo, $S_{.,}$Rodríguez, G., Espejo, J.A., Fernández-Bolaños, J., Heredia, A., Jiménez, A. (2008): Antioxidants from asparagus spears: Phenolics. Acta Horticulturae, 776: 247-254.

doi: http://dx.doi.org/10.17660/ActaHortic.2008.776.31

13. Hafizur, R.M., Kabir, N., Chishti, S. (2012): Asparagus officinalis extract controls blood glucose by improving insulin secretion and $\beta$-cell function in streptozotocin-induced type 2 diabetic rats. British Journal of Nutrition, 108: 1586-1595.

doi: http:// dx.doi.org/10.1017/S0007114511007148

14. Hammer, Ø., Harper, D.A.T., Ryan, P.D. (2001): PAST: Paleontological statistics software package for education and data analysis. Palaeontologia Electronica 4: 9. htm

http://palaeo-electronica.org/2001_1/past/issue1_01.

15. Krishnaiah, D., Sarbatly, R., Bono, A. (2007): Phytochemical antioxidants for health and medicine-A move towards nature. Biotechnology and Molecular Biology Review, 1: 97-104.

16. Lee, J.W., Lee, J.H., Yo I.H., Gorinstein, S., Bae, J.H., $\mathrm{Ku}$, Y.G. (2014): Bioactive compounds, antioxidant and binding activities and spear yield of Asparagus officinalis L. Plant Foods for Human Nutrition, 69: 175-181.

doi: http://dx.doi.org 10.1007/s11130-014-0418-9

17. Liu, C., Zhao, Y., Li, X., Jia, J., Chen, Y., Hua, Z. (2014): Antioxidant capacities and main reducing substance contents in 110 fruits and vegetables eaten in China. Food and Nutrition Sciences, 5: 293.

doi: http://dx.doi.org/10.4236/fns.2014.54036

18. Maeda, T., Honda, K., Sonoda, T., Motoki, S., Inoue, K., Suzuki, T., Oosawa, K., Suzuki, M. (2010): Light condition influences rutin and polyphenol contents in asparagus spears in the mother-fern culture system during the summer-autumn harvest. Journal of the Japanese Society for Horticultural Science, 79: 161-167.

doi: http://dx.doi.org 10.2503/jjshs1.79.161

19. Martins, D., Barros, L., Carvalho, A.M., Ferreira, I.C. (2011): Nutritional and in vitro antioxidant properties of edible wild greens in Iberian Peninsula traditional diet. Food Chemistry, 125: 488-494.

doi: http://dx.doi.org/10.1016/j.foodchem.2010.09.038

20. Makris, D.P., Rossiter, J.T. (2001): Domestic processing of onion bulbs (Allium cepa) and asparagus spears (Asparagus officinalis): Effect on flavonol content and antioxidant status. Journal of Agricultural and Food Chemistry, 49: 3216-3222.

doi: http://dx.doi.org/10.1021/jf001497z

21. Mensor, L.L., Menezes, F.S., Leitão, G.G., Reis, A.S., Santos, T.C.D., Coube, C.S., Leitão, S.G. (2001): Screening of Brazilian plant extracts for antioxidant activity by the use of DPPH free radical method. Phytotherapy Research, 15: 127-130.

doi: http://dx.doi.org/10.1002/ptr.687

22. Morales, P., Carvalho, A.M., Sánchez-Mata, M.C., Cámara, M., Molina, M., Ferreira, I.C. (2012): Tocopherol composition and antioxidant activity of Spanish wild vegetables. Genetic Resources and Crop Evolution, 59: 851-863.

doi: http://dx.doi.org/10.1007/s10722-011-9726-1

23. Nishimura, M., Ohkawara, T., Kagami-Katsuyama, H., Sato, H., Nishihira, J. (2013): Improvement of blood pressure, glucose metabolism, and lipid profile by the intake of powdered asparagus (蘆简 Lú Sŭn) bottom-stems and cladophylls. Journal of Traditional and Complementary Medicine, 3: 250.

doi: http://dx.doi.org/10.4103/2225-4110.119728

24. Palfi, M., Tomić-Obrdalj, H., Horvat, D. (2014): Zdravo povrće za zdravo srce: šparoge. Cardiologia Croatica, 9: 142-149.

25. Poljuha, D., Šola, I., Bilić, J., Dudaš, S., Bilušić, T., Markić, J., Rusak, G. (2015): Phenolic composition, antioxidant capacity, energy content and gastrointestinal stability of Croatian wild edible plants. European Food Research and Technology, 241: 573-585.

doi: http://dx.doi.org/10.1007/s00217-015-2486-y

26. Slinkard, K., Singleton, V.L. (1977): Total phenol analysis: automation and comparison with manual methods. American Journal of Enology and Viticulture, 28: 49-55.

27. Solana, M., Boschiero, I., Dall'Acqua, S., Bertucco, A. (2015): A comparison between supercritical fluid and 
pressurized liquid extraction methods for obtaining phenolic compounds from Asparagus officinalis L. The Journal of Supercritical Fluids, 100: 201-208.

doi: http://dx.doi.org/10.1016/j.supflu.2015.02.014

28. Sun, T., Powers, J.R., Tang, J. (2007): Evaluation of the antioxidant activity of asparagus, broccoli and their juices. Food Chemistry, 105: 101-106.

doi: http://dx.doi.org/10.1016/j.foodchem.2007.03.048

29. Takacs-Hajos, M., Zsombik, L. (2015): Total polyphenol, flavonoid and other bioactive materials in different asparagus cultivars. Notulae Botanicae Horti Agrobotanici Cluj-Napoca, 43: 59-63.

doi: http://dx.doi.org/10.15835/nbha4319720

30. Tiveron, A.P., Melo, P.S., Bergamaschi, K.B., Vieira, T.M., Regitano-d'Arce, M.A., Alencar, S.M. (2012): Antioxidant activity of Brazilian vegetables and its relation with phenolic composition. International Journal of Molecular Sciences, 13: 8943-8957.

doi: http://dx.doi.org/10.3390/ijms13078943
31. Wang, J., Liu, Y., Zhao, J., Zhang, W., Pang, X. (2013): Saponins extracted from by-product of Asparagus officinalis L. suppress tumour cell migration and invasion through targeting Rho GTPase signalling pathway. Journal of the Science of Food and Agriculture, 93: 1492-1498.

doi: http://dx.doi.org/10.1002/jsfa.5922

32. Waterhouse A.L. in: Wrolstad R.E., Acree T.E., An H., Decker E.A., Penner M.H., Reid D.S., Sporns P., Schwartz S.J., Shoemaker C.F. (Eds.). (2002): Current protocols in food analytical chemistry, John Wiley \& Sons Inc., New York, l:I1:I1.1.

33. Zhong, C., Jiang, C., Xia, X., Mu, T., Wei, L., Lou, Y., Bi, X. (2015): Antihepatic fibrosis effect of active components isolated from green asparagus (Asparagus officinalis L.) involves the inactivation of hepatic stellate cells. Journal of Agricultural and Food Chemistry, 63: 6027-6034. doi: http://dx.doi.org/10.1021/acs.jafc.5b01490

34. Žaper, A. (2004): Kulinarstvo - dio kulturne baštine u hrvatskoj turističkoj ponudi. Naše more, 51: 227-238.

\section{SADRŽAJ UKUPNIH POLIFENOLA I ANTIOKSIDACIJSKA AKTIVNOST SAMONIKLE I KULTIVIRANE ŠPAROGE U HRVATSKOJ}

\section{SAŽETAK}

Zbog brojnih nutritivnih vrijednosti i potencijalnoga pozitivnoga učinka na ljudsko zdravlje, šparoga se pokazala kao interesantna kultura za konzumaciju te predmet brojnih znanstvenih ispitivanja. Samonikla šparoga (Asparagus acutifolius L.) raste duž Jadranske obale i otoka, dok se kultivirana šparoga (Asparagus officinalis L.) uglavnom uzgaja u istočnome dijelu Hrvatske. Ovim istraživanjem određivan je ukupni sadržaj polifenola (spektofotometrijski) $i$ antioksidativna aktivnost (DPPH) kod samoniklih i kultiviranih šparoga. Rezultati su pokazali da nema statistički značajne razlike u sadržaju ukupnih polifenola između samoniklih i kultiviranih šparoga. Najviša vrijednost ukupnih polifenola samoniklih šparoga iznosila je 6,20 [mg GAE/g svježe tvari], odnosno 49,60 [mg GAE/g suhe tvari], dok je kod kultiviranih šparoga bila 4,52 [mg GAE/g svježe tvari], odnosno 50,93 [mg GAE/g suhe tvari]. Antioksidativna aktivnost mjerena DPPH (2,2-difenil-1-pikrilhidrazil) metodom, pokazala je statistički značajne razlike. Veća je antioksidativna aktivnost izmjerena kod kultiviranih, nego kod samoniklih šparoga. Također je utvrđeno da porastom polifenola raste antioksidativna aktivnost, ali više kod kultiviranih šparoga. Temeljem rezultata, zaključujemo da je kultivirana šparoga odlična alternativa samonikloj, koja bi trebala biti zaštićena od pretjeranog ubiranja, kako bi se zaštitila prirodna raznolikost obale i otoka.

Ključne riječi: Asparagus acutifolius L, Asparagus officinalis L, DPPH, ukupni polifenoli, antioksidacijska aktivnost

(Received on 11 January 2017; accepted on 15 May 2017 - Primljeno 11. siječnja 2017.; prihvaćeno 15. svibnja 2017.) 